\title{
Repetitive in vivo treatment with human recombinant interleukin-1 $\beta$ modifies Beta-cell function in normal rats
}

\author{
L.D.Wogensen ${ }^{1}$, J.Reimers ${ }^{1}$, J.Nerup ${ }^{1}$, V.Kolb-Bachofen ${ }^{2}$, K.-D.Kröncke ${ }^{2}$,T. Almdal ${ }^{1,3}$ and T. Mandrup-Poulsen $^{1}$ \\ ${ }^{1}$ Steno Memorial and Hvidøre Hospital, and Hagedorn Research Laboratory, Gentofte, Denmark \\ ${ }^{2}$ Heinrich-Heine-Universität Düsseldorf, Abteilung für Immunbiologie, Düsseldorf, FRG, and \\ ${ }^{3}$ Medical Department A, Rigshospitalet, Copenhagen, Denmark
}

\begin{abstract}
Summary. It is unknown whether interleukin-1 exerts a bimodal effect on Beta-cell function in vivo, and whether interleukin-1 has a diabetogenic action in normal animals. We therefore studied: (a) acute effects $2 \mathrm{~h}$ after an intraperitoneal bolus injection of $4 \mu \mathrm{g}$ of recombinant human interleukin- $1 \beta$ per $\mathrm{kg}$ body weight on blood glucose, plasma levels of insulin, glucagon and corticosterone in Wistar Kyoto rats, either untreated or pre-treated with $4 \mu \mathrm{g} / \mathrm{kg}$ of interleukin-1 daily for 3 or 5 days; (b) the cumulative effects of repetitive intraperitoneal injections of $4 \mu \mathrm{g} / \mathrm{kg}$ interleukin- 1 on blood glucose, glucose tolerance, plasma levels of insulin, glucagon and corticosterone, pancreatic insulin content and pancreatic ultrastructure; and (c) blood glucose and plasma concentrations of insulin, glucagon and corticosterone $10 \mathrm{~h}$ after the last of five intraperitoneal injections of interleukin-1, at which time point the inhibitory effect of short-term interleukin-1 exposure on insulin secretion reaches its nadir in vitro. A single injection of $4 \mu \mathrm{g} / \mathrm{kg}$ of interleukin- 1 caused a slight, but significant lowering of blood glucose $2 \mathrm{~b}$ after interleukin-1 injection with no significant changes in plasma insulin and in spite of increases in plasma glucagon and corticosterone. A lowering of blood glucose $2 \mathrm{~h}$ after interleukin- 1 administration was reproduced with 40 , but not $0.4 \mu \mathrm{g} / \mathrm{kg}$ of interleukin- 1 , and was also seen in interleukin-1 pre-treated rats. Two hours after the fifth injection of interleukin-1, intraperitoneal glucose tolerance was impaired
\end{abstract}

with elevated plasma insulin and corticosterone levels and increased pancreatic insulin content, indicating a state of insulin resistance. Blood glucose levels significantly increased time-dependently $4-10 \mathrm{~h}$ after the third and fifth injection of interleukin-1, and diabetic values (blood glucose $>11.0 \mathrm{mmol} / \mathrm{l}$ ) were observed 6 and $10 \mathrm{~h}$ after the fifth injection of interleukin-1. Ten hours after the fifth injection of interleukin-1, diabetic blood glucose levels were observed together with a $50 \%$ reduction in plasma insulin concentration. Ultrastructural examination showed no signs of Betacell lysis. In conclusion, interleukin-1 has bimodal effects on glucose homeostasis in vivo, a slight lowering of the blood glucose followed by impaired glucose tolerance and later by diabetic blood glucose levels. Two hours after the last of five daily injections of interleukin-1 impaired glucose tolerance is primarily caused by a state of insulin resistance, whereas diabetic blood glucose levels are associated with inhibition of insulin secretion. Thus, interleukin-1 causes a diabetic state in normal animals, but it remains to be demonstrated that administration of interleukin-1 to normal animals leads to permanent diabetes due to Beta-cell destruction.

Key words: Interleukin- $1 \beta$, Beta cells, morphology, glucose tolerance, Type 1 (insulin-dependent) diabetes mellitus, pathogenesis, rats.
The cytokine interleukin-1 (IL-1) modulates insulin secretion from isolated islets in a time- and dose-dependent bimodal fashion, stimulation of Beta-cell function followed by inhibition $[1,2]$. Interleukin-1 has also been shown to be preferentially Beta-cell cytotoxic in vitro and may be a major effector molecule in the pathogenesis of Type 1 (insulin-dependent) diabetes mellitus [1]. Chronic administration of IL-1 to animals with spontaneouslydeveloping Type 1 diabetes modifies the development of diabetes probably due to an immunomodulatory effect of IL-1 [3-5]. However, it is unknown whether IL-1 exerts a bimodal effect on Beta-cell function in vivo and whether IL-1 has a diabetogenic action in normal animals.

In vivo bolus administration of IL-1 or acute stimulation of endogenous IL-1 production have been reported to reduce the blood glucose (BG) concentration [6-9] and to cause hyperinsulinaemia in normal animals [6, 7, 9-12]. Furthermore, a single intraperitoneal (i.p.) injection of recombinant IL- $1 \beta$ to normal rats produces a lowering of the $\mathrm{BG}$ during an i.p. glucose tolerance test (IPGT) performed $2 \mathrm{~h}$ after IL-1 injection [13]. In most studies the hypoglycaemic effect of IL-1 has been ascribed to the stimula- 
tion of insulin secretion by the cytokine, either by directly affecting the Beta cells $[7,9]$ or mediated by humoral signals from the central nervous system [10]. However, glucose disposal may also be affected by IL-1 in vivo $[8,11]$.

Repeated injections of human rIL-1 $\beta$ (rIL-1 $\beta$ ) in vivo inhibited glucose-stimulated insulin release from isolated islets [14] and the isolated perfused pancreas [15] and induced a transiently impaired glucose tolerance in normal rats [13]. These observations suggest that repeated exposure to rIL- $1 \beta$ may inhibit Beta-cell function in vivo. However, plasma insulin levels were not determined in previous studies of long-term rIL- $1 \beta$ administration. Thus, the aim of the present study was to test whether repeated injections of human rIL- $1 \beta$ could induce insulinpoenic diabetes in normal rats.

\section{Materials and methods}

\section{Animals}

Inbred male Wistar Kyoto rats (200-240 g) (Møllegaarden, Lille Skensved, Denmark), were housed under controlled conditions of light, humidity and temperature for 10 days before the experiments. Rats were randomized to i.p. injections of either $\mathrm{rIL}-1 \beta$ or vehicle in an identical volume which were administrated at 09.00 hours. Body temperature was measured before and $2 \mathrm{~h}$ after injection by means of a rectal thermometer (Medical Precision Thermometer, Ellab Dh 852 , Copenhagen, Denmark). Only rats exhibiting a rectal temperature $>37.5^{\circ} \mathrm{C}$ after injection of rIL- $1 \beta$ were included in the study [13]. The animals in the rIL- $1 \beta$ group were given an excess $(100 \mathrm{~g})$ of standard rat chow (Altromin, Chr.Petersen A/S, Ringsted, Denmark) $7 \mathrm{~h}$ after injection. Rats in the control group were pair-fed with the group given $4 \mu \mathrm{g} / \mathrm{kg}$ body weight of rIL- $1 \beta$ in the following way: every morning the residual food was removed from the rIL-1 $\beta$ treated rats and weighed. An amount of food equal to the amount consumed by the rIL- $1 \beta$ treated rats during the preceding $24-\mathrm{h}$ period was then offered to the control rats. Thus, the control rats were given $7.9 \pm 0.03 \mathrm{~g} / 100 \mathrm{~g}$ body weight (in experiment 3 : $6.4 \pm 1.1 \mathrm{~g} / 100 \mathrm{~g}$ body weight). Body weight was measured daily.

\section{Preparation of $r I L-1 \beta$}

Recombinant human IL-1 $\beta$ (Batch C04) was expressed in Escherichia coli. It corresponded to the authentic 153 amino acid natural IL$1 \beta$, exhibiting the correct $\mathrm{N}$-terminal amino acid in position 117 (alanine) [16]. Recombinant IL-1 $\beta$ was purified as described [16], but using $34 \mu \mathrm{m}$ Q HR Sepharose (Pharmacia-LKB, Stockholm Sweden) instead of FF-Q Sepharose, and omitting the final Sephadex G75 gel filtration. The protein concentration was determined using $E=0.60(277 \mathrm{~nm}, 0.1 \%)[17]$. The specific biological activity of rIL-1 $\beta$ was 400 World Health Organisation U/ng as estimated by the mouse co-stimulatory thymocyte assay [18]. The physiochemical properties of rIL- $1 \beta$ were identical to natural IL- $1 \beta$ [18]. Recombinant IL- $1 \beta$ was diluted in sterile, endotoxin-free $0.9 \% \mathrm{NaCl}$ containing $0.1 \%$ strain-identical rat serum. The volume injected ranged from 0.5 to $0.6 \mathrm{ml}$ dependent upon the final concentration of $\mathrm{IL}-1 \beta$ as determined by an enzyme-linked immunosorbent assay technique (ELISA) [18]. Endotoxin was not detectable in the rIL- $1 \beta$ solution or the vehicle by the Limulus amoebocyte test [19].

\section{Protocols}

Experiment 1 was designed to study the effect of a single injection of rIL- $1 \beta$ on BG and plasma insulin, glucagon and corticosterone concentrations, and to investigate putative changes in pancreatic weight, pancreatic insulin content, BG, and plasma concentrations of in- sulin, glucagon and corticosterone during 5 days of treatment with rIL- $1 \beta$. The rats were treated daily at 09.00 hours with rIL- $1 \beta$ ( $4 \mu \mathrm{g} / \mathrm{kg}$ body weight) or vehicle. Rats were decapitated $2 \mathrm{~h}$ after 1,3 or 5 injections of rIL- $1 \beta$ or vehicle, or before injection day $1,24 \mathrm{~h}$ after the second injection (day 3 at 09.00 hours) or $24 \mathrm{~h}$ after the fourth injeciton (day 5 at 09.00 hours) ( $n=10$ in each group).

Experiment 2 was designed to test the effect of repeated injections of rIL- $1 \beta$ on an IPGT, evaluated by BG, pancreatic insulin content, and plasma concentrations of insulin, glucagon and corticosterone. The rats were injected with $4 \mu \mathrm{g} / \mathrm{kg}$ body weight of rIL- $1 \beta$ at 09.00 hours on 5 consecutive days and were decapitated 30,60 , and 120 min after an i.p. challenge with $0.2 \mathrm{~g} \mathrm{D}$-glucose $/ 100 \mathrm{~g}$ body weight at 11.00 hours on day $5(0.2 \mathrm{~g} \mathrm{D}$-glucose $/ \mathrm{ml})(n=10$ in each group). Blood glucose concentration was determined in all rats $15 \mathrm{~min}$ after glucose administration. Only rats showing a BG level 3 SD higher than before the glucose injection were included in the statistical analysis.

Experiment 3 was designed to study whether the effect on BG depended on time and rIL- $1 \beta$ dose. The rats were injected with 0.4 $(n=10), 4.0(n=12)$ or $40(n=12) \mu \mathrm{g} / \mathrm{kg}$ body weight of $\mathrm{IL}-1 \beta$ daily at 09.00 hours on 5 consecutive days. Control rats treated with vehicle were either pair-fed with the rats injected with $4 \mu \mathrm{g} / \mathrm{kg}$ body weight of IIL-1 $\beta(n=8)$, or fed ad libitum $(n=8)$. Rats not treated at all $(n=8)$ were included as a control group. Blood glucose concentration was measured before and $2,4,6$, and $10 \mathrm{~h}$ after injection on day 1,3 , and 5 . Ten hours after the last injection on day 5 the rats were killed by decapitation.

Experiment 4 was performed to study the ultrastructure of the endocrine pancreas after injections with $4 \mu \mathrm{g} / \mathrm{kg}$ body weight of $\mathrm{rIL}-1 \beta$ or vehicle daily at 09.00 hours on 5 consecutive days. On day 5 the rats were randomized for isolation of the pancreas and were anaesthetized by an i.p. injection of sodium pentobarbital $(50 \mathrm{mg} / \mathrm{kg})$ at 11.00 hours ( $n=4$ in each group).

In experiments 1-3, trunk blood was collected in tubes containing $50 \mu 130 \%$ EDTA and $125 \mu$ aprotinin $(20000 \mathrm{U} / \mathrm{ml})$ and kept at $4{ }^{\circ} \mathrm{C}$ until centrifugation ( $4000 \mathrm{rev} / \mathrm{min}, 10 \mathrm{~min})$. The plasma was frozen $\left(-20^{\circ} \mathrm{C}\right)$ for measurements of insulin, glucagon, and corticosterone concentrations. The pancreata were excised, weighed, snap-frozen in liquid nitrogen and stored for approximately one month at $-20^{\circ} \mathrm{C}$ before extraction.

\section{Hormone analysis in plasma}

The plasma insulin concentration was measured by radioimmunoassay [20] using rat standards and anti-insulin serum M8170. The detection limit was $3 \mathrm{pmol} / \mathrm{l}$. Inter- and intra-assay coefficients of variation were $15 \%$ and $5 \%$, respectively. The plasma concentrations of corticosterone and glucagon were measured by commercially available RIA-methods (Novo-Nordisk A/S, Bagsværd, Denmark). Glucagon was extracted by ethanol precipitation [21]. The detection limit of the assay was $20-25 \mathrm{ng} / \mathrm{l}$ and inter- and intra-assay coefficients of variation were $18.3 \%$ and $11.6 \%$, respectively. The detection limit of the corticosterone assay was $25 \mathrm{ng} / \mathrm{ml}$ and inter- and intra-assay coefficients of variation were $7 \%$ and $6.3 \%$, respectively. For BG determination $10 \mu \mathrm{l}$ blood was drawn from a tail vein and was analysed by a Kobas MIRA automatic analyser using the dehydrogenase method.

\section{Pancreas extraction}

Extraction with phosphoric acid ethanol was performed as previously described [22]. The insulin concentration in pancreatic extracts was determined by ELISA [15]. Our working range was $2 \mathrm{pmol} / 1-1.0 \mathrm{nmol} / 1$. The intra-assay coefficients of variation for three independent samples: $0.12 \mathrm{nmol} / \mathrm{l}(n=6), 0.23 \mathrm{nmol} / \mathrm{l}(n=6)$ and $0.45 \mathrm{nmol} / \mathrm{l}(n=6)$ were: $0 \%, 2.4 \%$ and $3.7 \%$, respectively. The inter-assay coefficients of variation for two independent samples, R1 and R2, each assayed in the dilutions $1: 2(0.91$ and $0.83 \mathrm{nmol} / \mathrm{l}), 1: 4$ $(0.44$ and $0.41 \mathrm{nmol} / 1), 1: 8(0.20$ and $0.19 \mathrm{nmol} / \mathrm{l})$ and $1: 16$ (both 
Table 1. Body weight (BW), blood glucose concentration (BG) and plasma concentrations of insulin, glucagon and corticosterone $2 \mathrm{~h}$ after 1,3 or 5 injections of recombinant interleukin- $1 \beta$ (rIL- $1 \beta$ ) or vehicle. The number of rats at each blood sampling was 10

\begin{tabular}{|c|c|c|c|c|c|c|}
\hline \multirow[b]{2}{*}{$\begin{array}{l}\text { No. of injec- } \\
\text { tions }\end{array}$} & \multicolumn{2}{|l|}{ Day 1} & \multicolumn{2}{|l|}{ Day 3} & \multicolumn{2}{|l|}{ Day 5} \\
\hline & 1 & & 3 & & 5 & \\
\hline Group & Vehicle & rIL- $1 \beta$ & Vehicle & IIL- $1 \beta$ & Vehicle & rIL- $1 \beta$ \\
\hline $\begin{array}{l}\text { BW } \\
(\mathrm{g})\end{array}$ & $\begin{array}{r}211 \\
\pm 9.1\end{array}$ & $\begin{array}{r}213 \\
+8.9\end{array}$ & $\begin{array}{r}206 \\
\pm 10.2\end{array}$ & $\begin{array}{c}214 \\
\pm 10.0\end{array}$ & $\begin{array}{r}216 \\
\pm 11.3\end{array}$ & $\begin{array}{r}211 \\
\pm 8.0\end{array}$ \\
\hline $\begin{array}{l}\text { BG } \\
(\mathrm{mmol} / \mathrm{)})\end{array}$ & $\begin{array}{r}5.5 \\
\pm 0.2\end{array}$ & $\begin{aligned} & 5.1^{\mathrm{b}} \\
\pm & 0.4\end{aligned}$ & $\begin{array}{r}4.9 \\
\pm 0.4\end{array}$ & $\begin{array}{r}4.8 \\
\pm 0.4\end{array}$ & $\begin{array}{r}5.4 \\
\pm 0.7\end{array}$ & $\begin{array}{r}4.5 \\
\pm 0.6\end{array}$ \\
\hline $\begin{array}{l}\text { Insulin } \\
(\mathrm{pmol} / \mathrm{l})\end{array}$ & $\begin{array}{r}165 \\
\pm \quad 39\end{array}$ & $\begin{array}{r}151 \\
\pm \quad 50\end{array}$ & $\begin{array}{r}186 \\
\pm \quad 51\end{array}$ & $\begin{array}{r}264 \\
\pm 107\end{array}$ & $\begin{array}{r}223 \\
\pm 105\end{array}$ & $\begin{array}{r}224 \\
\pm 185\end{array}$ \\
\hline $\begin{array}{l}\text { Glucagon } \\
(\mathrm{ng} / \mathrm{l})\end{array}$ & $\begin{array}{r}185 \\
\pm \quad 35\end{array}$ & $\begin{aligned} & 261^{\mathrm{b}} \\
& \pm \quad 54\end{aligned}$ & $\begin{array}{r}163 \\
\pm \quad 48\end{array}$ & $\begin{aligned} & 289^{\mathrm{b}} \\
\pm & 82\end{aligned}$ & $\begin{array}{r}184 \\
\pm \quad 55\end{array}$ & $\begin{array}{r}231 \\
\pm \quad 68\end{array}$ \\
\hline $\begin{array}{l}\text { Cortico- } \\
\text { sterone } \\
(\mu g / 1)\end{array}$ & $\begin{array}{r}274 \\
\pm 101\end{array}$ & $\begin{array}{r}423^{b} \\
\pm \quad 87\end{array}$ & $\begin{array}{r}343 \\
\pm 114\end{array}$ & $\begin{array}{r}462^{\mathrm{a}} \\
\pm \quad 84\end{array}$ & $\begin{array}{r}288 \\
\pm \quad 65\end{array}$ & $\begin{array}{r}455^{c} \\
\pm \quad 64\end{array}$ \\
\hline
\end{tabular}

Means \pm SD. ${ }^{\mathrm{a}} p<0.05,{ }^{\mathrm{b}} p<0.01,{ }^{\circ} p<0.001$ comparing the $\mathrm{rIL}-1 \beta$ group and the control group

$0.11 \mathrm{nmol} / \mathrm{l}$ ), were $15.7 \%, 14 \%, 10.5 \%$ and $10 \%$, and $10 \%, 11 \%$, $12 \%$ and $22 \%$, respectively.

\section{Islet morphology at the ultrastructural level}

The splenic part of the pancreas was removed and cut into approximately $1 \times 1 \mathrm{~mm}$ pieces, while bathed in $1 \%$ glutaraldehyde in natriumcacodylate buffer $(100 \mathrm{mmol} / \mathrm{l} \mathrm{Na}$-cacodylate, $2 \mathrm{mmol} / \mathrm{C} \mathrm{Ca}$, $80 \mathrm{mmol} / \mathrm{l}$ saccharose, $\mathrm{pH} 7.2$ ). After further fixation for $1 \mathrm{~h}$ at $4{ }^{\circ} \mathrm{Cin}$ $1 \%$ glutaraldehyde, the tissue pieces were washed and postfixed with cacodylate-buffered $\mathrm{OsO}_{4}(1.5 \%)$ for $2 \mathrm{~h}$. The specimens were washed three times in cacodylate buffer and were stored in this buffer for a maximum of 10 days. After dehydration in graded ethanol dilutions, the tissue was embedded in epoxy resin according to Spurr [23]. All specimens were sectioned semi-thin and screened for islets after staining with toluidine blue. Islet-containing tissue was sectioned ultra-thin at random and was evaluated by the morphologist in a blinded design. For quantitation of possible lytic events the number of Alpha and Beta cells were counted on photo micrographs at a final magnification of $5000 \times$. Lysis at low-power magnification was defined as opaque cytoplasm without the usual intermediate contrast. Lysis was further confirmed by screening the respective islet cells at higher magnifications for disrupted cytoplasmic membranes.

\section{Statistical analysis}

Results are expressed as means \pm SD. The two-tailed Mann-Whitney rank sum test and the Wilcoxon-Pratt test were used to test differences between sets of unpaired data and paired data, respectively. The Kruskal-Wallis test was used for comparing more than two sets of unpaired data. Fisher's exact test was used in the morphology study. The level of significance chosen was $5 \%$.

\section{Results}

\section{Experiment 1}

Effects of $r I L-1 \beta(4 \mu \mathrm{g} / \mathrm{kg})$ on blood glucose and plasma concentrations of insulin, glucagon and corticosterone evaluated $2 \mathrm{~h}$ after one, three or five injections of $r I L-1 \beta$ or vehicle. Two hours after a single injection of rIL-1 $\beta$ the BG was lower compared to the control group with no concomitant changes in plasma level of insulin and in spite of increased plasma levels of glucagon and corticosterone (Table 1). After the third injection with cytokine only increases in plasma levels of glucagon and corticosterone were seen, with no changes in $\mathrm{BG}$ and insulin concentrations when compared to the control group. In rats pretreated for 4 days with rIL- $1 \beta$, only plasma corticosterone was elevated $2 \mathrm{~h}$ after the fifth injection of rIL- $1 \beta$, with no changes in other parameters (Table 1).

Effects of rIL-1 $(4 \mu \mathrm{g} / \mathrm{kg})$ on pancreatic weight, pancreatic insulin content, $B G$ and plasma concentrations of insulin, glucagon and corticosterone evaluated $24 \mathrm{~h}$ after two or four injections of $r I L-1 \beta$ or vehicle. In rats studied $24 \mathrm{~h}$ after the second injection of rIL- $1 \beta$ the BG was significantly elevated, despite increased insulin levels. The plasma concentrations of glucagon and corticosterone were unaffected, as were the pancreatic weight and insulin content (Table 2). Twenty-four hours after the fourth rIL-1 $\beta$ injection the pancreatic insulin content was increased despite reduced pancreatic wet and dry weights. No differences were seen in BG, plasma levels of insulin, glucagon or corticosterone (Table 2).

\section{Experiment 2}

Blood glucose, and plasma concentrations of insulin, glucagon and corticosterone during an IPGT $2 \mathrm{~h}$ after five injections of $r I L-1 \beta$. Before the IPGT BG and plasma levels

Table 2. Body weight (BW), pancreatic weight, pancreatic insulin content, blood glucose concentration (BG), and plasma concentrations of insulin, glucagon and corticosterone before $(0)$ and $24 \mathrm{~h}$ after 2 and 4 injections of recombinant interleukin- $1 \beta(\mathrm{rIL}-1 \beta)$ or vehicle. The number of rats at each blood sampling was 10

\begin{tabular}{|c|c|c|c|c|c|c|}
\hline \multirow[b]{2}{*}{$\begin{array}{l}\text { No. of injec- } \\
\text { tions }\end{array}$} & \multicolumn{2}{|l|}{ Day 1} & \multicolumn{2}{|l|}{ Day 3} & \multicolumn{2}{|l|}{ Day 5} \\
\hline & 0 & & 2 & & 4 & \\
\hline Group & Vehicle & rIL-1 $\beta$ & Vehicle & rIL- $1 \beta$ & Vehicle & rIL $-1 \beta$ \\
\hline $\begin{array}{l}\text { BW } \\
(\mathrm{g})\end{array}$ & $\begin{array}{r}211 \\
\pm 9.4\end{array}$ & $\begin{array}{r}217 \\
+9.4\end{array}$ & $\begin{array}{r}209 \\
+8.7\end{array}$ & $\begin{array}{r}210 \\
\pm 8.4\end{array}$ & $\begin{array}{r}210 \\
\pm 9.3\end{array}$ & $\begin{array}{r}216 \\
\pm 8.0\end{array}$ \\
\hline $\begin{array}{l}\text { Pancreas wet } \\
\text { weight } \\
\text { (g) }\end{array}$ & $\begin{array}{r}1.0078 \\
\pm 0.16\end{array}$ & $\begin{array}{l}1.0631 \\
\pm 0.13\end{array}$ & $\begin{array}{l}1.1837 \\
\pm 0.33\end{array}$ & $\begin{array}{r}0.9370 \\
\pm 0.22\end{array}$ & $\begin{array}{r}0.9633 \\
\pm 0.14\end{array}$ & $\begin{array}{l}0.8170^{\mathrm{a}} \\
\pm 0.09\end{array}$ \\
\hline $\begin{array}{l}\text { Pancreas dry } \\
\text { weight } \\
\text { (g) }\end{array}$ & $\begin{array}{r}0.3723 \\
\pm 0.08\end{array}$ & $\begin{array}{l}0.4050 \\
\pm 0.07\end{array}$ & $\begin{array}{r}0.4632 \\
\pm 0.16\end{array}$ & $\begin{array}{r}0.3348 \\
\pm 0.11\end{array}$ & $\begin{array}{r}0.3442 \\
\pm 0.08\end{array}$ & $\begin{array}{l}0.2530^{\circ} \\
\pm 0.04\end{array}$ \\
\hline $\begin{array}{l}\text { Total insulin } \\
\text { (nmol/pan- } \\
\text { creas) }\end{array}$ & $\begin{array}{r}6.3 \\
\pm 2.2\end{array}$ & $\begin{array}{r}6.7 \\
\pm 2.4\end{array}$ & $\begin{array}{r}7.0 \\
\pm 1.9\end{array}$ & $\begin{array}{r}7.8 \\
\pm 1.4\end{array}$ & $\begin{array}{r}8.4 \\
\pm 1.6\end{array}$ & $\begin{array}{r}10.9^{b} \\
\pm 1.4\end{array}$ \\
\hline $\begin{array}{l}\mathrm{BG} \\
(\mathrm{mmol} / \mathrm{l})\end{array}$ & $\begin{array}{r}6.0 \\
\pm 0.4\end{array}$ & $\begin{array}{r}6.1 \\
\pm 0.5\end{array}$ & $\begin{array}{r}5.0 \\
\pm 0.3\end{array}$ & $\begin{aligned} & 5.7^{\mathrm{b}} \\
\pm & 0.6\end{aligned}$ & $\begin{array}{r}5.2 \\
\pm 0.8\end{array}$ & $\begin{array}{r}4.8 \\
\pm 0.6\end{array}$ \\
\hline $\begin{array}{l}\text { Insulin } \\
(\mathrm{pmol} / \mathrm{l})\end{array}$ & $\begin{array}{r}237 \\
\pm \quad 53\end{array}$ & $\begin{array}{r}214 \\
\pm \quad 48\end{array}$ & $\begin{array}{r}168 \\
\pm \quad 55\end{array}$ & $\begin{array}{r}260^{\mathrm{a}} \\
\pm \quad 79\end{array}$ & $\begin{array}{r}176 \\
\pm \quad 45\end{array}$ & $\begin{array}{r}184 \\
\pm \quad 32\end{array}$ \\
\hline $\begin{array}{l}\text { Glucagon } \\
(\mathrm{ng} / \mathrm{l})\end{array}$ & $\begin{array}{r}178 \\
\pm \quad 53\end{array}$ & $\begin{array}{r}165 \\
\pm \quad 48\end{array}$ & $\begin{array}{r}206 \\
+\quad 47\end{array}$ & $\begin{array}{r}200 \\
\pm \quad 67\end{array}$ & $\begin{array}{r}200 \\
\pm \quad 47\end{array}$ & $\begin{array}{r}180 \\
\pm \quad 29\end{array}$ \\
\hline $\begin{array}{l}\text { Corticosterone } \\
(\mu \mathrm{g} / 1)\end{array}$ & $\begin{array}{r}345 \\
\pm \quad 76\end{array}$ & $\begin{array}{r}362 \\
\pm \quad 52\end{array}$ & $\begin{array}{r}419 \\
\pm \quad 90\end{array}$ & $\begin{array}{r}308 \\
+\quad 96\end{array}$ & $\begin{array}{r}429 \\
\pm 131\end{array}$ & $\begin{array}{r}372 \\
+103\end{array}$ \\
\hline
\end{tabular}

Means $\pm \mathrm{SD}$. a $p<0.05,{ }^{\mathrm{b}} p<0.01$ comparing the rIL- $1 \beta$ group with the control group 

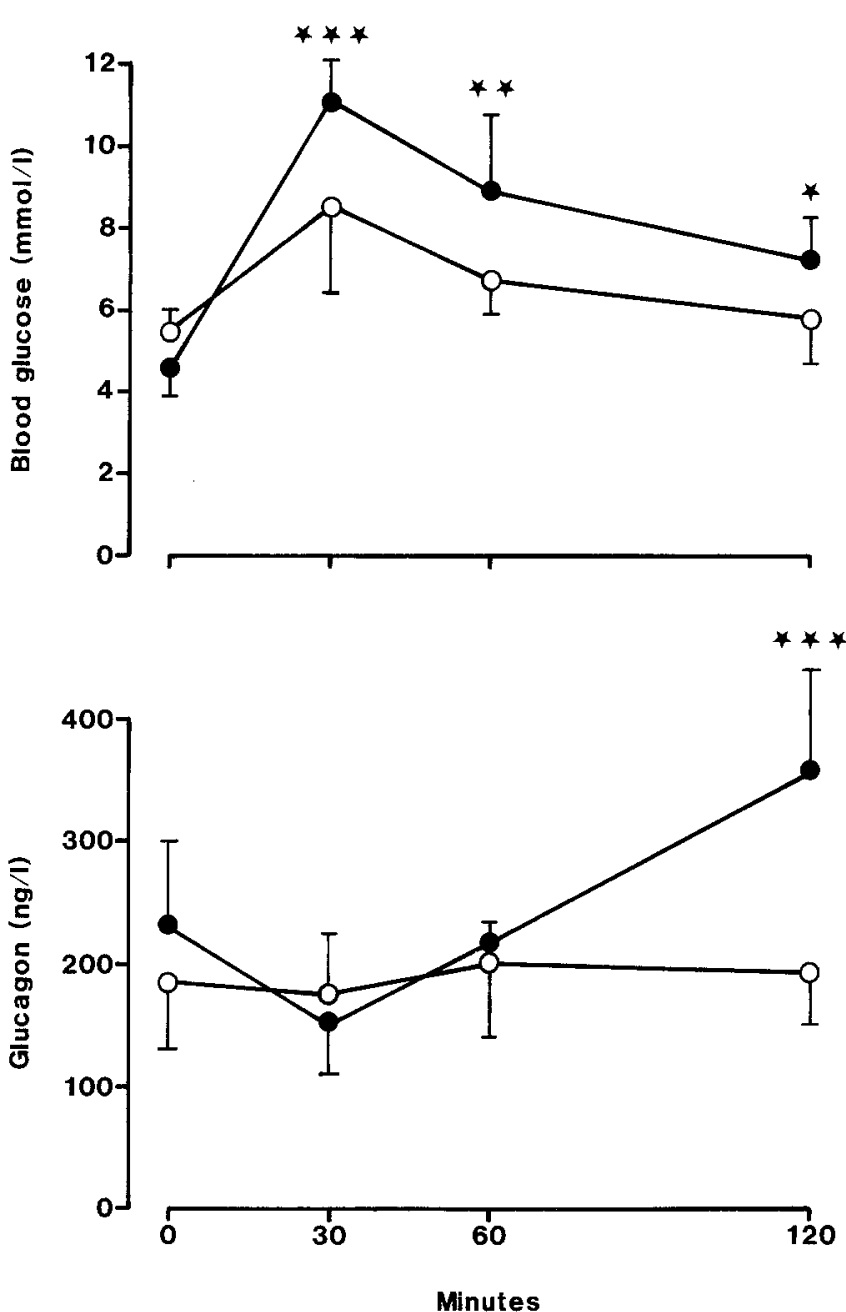

Fig. 1. Blood glucose and plasma concentrations of insulin, glucagon and corticosterone during an i.p. glucose tolerance test $2 \mathrm{~h}$ after the last of five daily injections of $4 \mu \mathrm{g} / \mathrm{kg}$ of human recombinant interleukin- $1 \beta(n=10)(\bullet)$ or vehicle $(n=10)(0)$. Rats were injected at

of insulin and glucagon were similar, whereas the plasma concentration of corticosterone was higher in the rIL-1 $\beta$ group than in the control group (Table 2 and Fig. 1). During the IPGT the BG was higher in the rIL- $1 \beta$ group compared with the pair-fed control group. The BG did not reach baseline level $120 \mathrm{~min}$ after injection of glucose as it did in the control group $(p<0.001)$ (Fig. 1). Plasma insulin levels increased markedly $30 \mathrm{~min}$ after glucose administration in the rIL- $1 \beta$ treated animals $(p<0.001)$, returning to the baseline level at $120 \mathrm{~min}$. In the control group, no significant increase in plasma insulin was observed $(p=0.06)$ (Fig. 1). The plasma glucagon level increased 120 min after glucose injection in the rIL- $1 \beta$ group. No significant changes in plasma glucagon were observed in the control group. The plasma level of corticosterone decreased in the rIL-1 $\beta$ group $(p<0.001)$. In the control group the concentration of corticosterone increased from 0 to $30 \mathrm{~min}$, but was similar to the baseline level at $120 \mathrm{~min}$ (Fig. 1). No changes were observed in the total extractable insulin content in the two groups during the IPGT (data not shown).
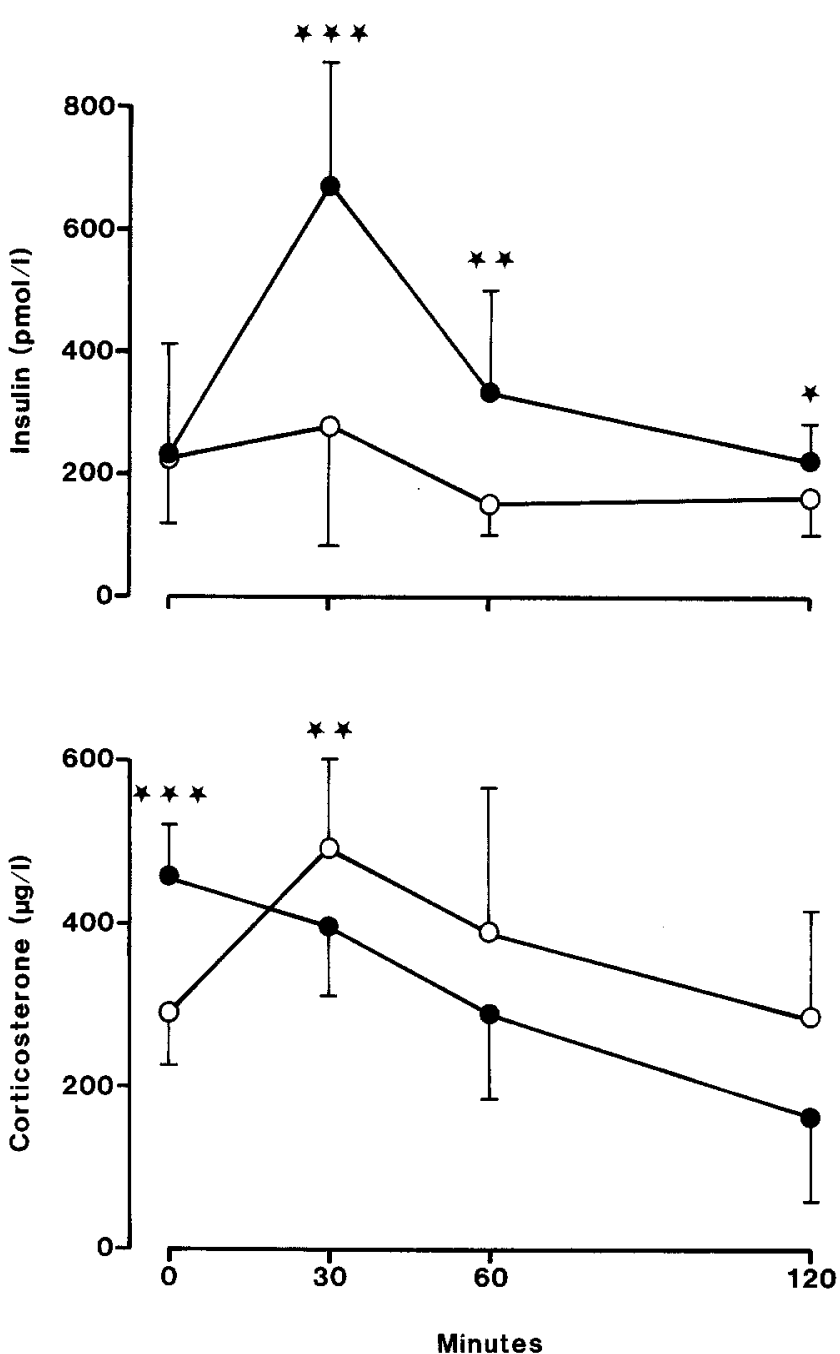

09.00 hours on each of five consecutive days and were decapitated for sampling of trunk blood before and 30,60 and 120 min after the i. p. glucose challenge $(0.2 \mathrm{~g} \mathrm{D}$-glucose $/ 100 \mathrm{~g}$ body weight). Means \pm SD. $* p<0.05, * * p<0.01, * * * p<0.001$

\section{Experiment 3}

The influence of time and different doses of $r I L-1 \beta$ on blood glucose. Four and $40 \mu \mathrm{g} / \mathrm{kg}$ body weight of rIL-1 $\beta$ induced a significant decrease in BG $2 \mathrm{~h}$ after one and three injections (Table 3). A preprandial increase in $\mathrm{BG}$ was obvious $6 \mathrm{~h}$ after three rIL- $1 \beta$ injections, and 4 and $6 \mathrm{~h}$ after five injections of cytokine. BG was much higher in all the rIL-1 $\beta$ treated rats compared with the control rats $(p<0.01)$ (Table 3$)$. Postprandial BG $10 \mathrm{~h}$ after one, three or five injections of $\mathrm{r} \Pi-1 \beta$ or vehicle was increased in most groups $(p<0.01)$ (Table 3$)$. Ten hours after three injections of rIL-1 $\beta$ the BG concentration was higher, irrespective of dose, than in the control groups, and BG was even higher after five injections of IIL- $1 \beta(p<0.01)$ (Table 3). Ten hours after the last injection of rIL- $1 \beta$ on day $5(4 \mu \mathrm{g} / \mathrm{kg})$, hyperglycaemia was accompanied by a marked reduction in plasma insulin concentration compared with the pair-fed control group $(p<0.0001)$ (Fig. 2). Plasma levels of glucagon and corticosterone, respectively, were similar to levels obtained in pair-fed con- 
Table 3. The effect of $0.4(n=10), 4.0(n=12)$ and $40(n=12) \mu \mathrm{g} / \mathrm{kg}$ body weight $(\mathrm{BW})$ of recombinant interleukin- $1 \beta$ (rIL- $1 \beta)$ on blood glucose $(\mathrm{BG})(\mathrm{mmol} / \mathrm{l})$ before and $2,4,6$ and $10 \mathrm{~h}$ after 1,3 and 5 injections of the cytokine. Rats treated with vehicle and pair-fed to the rlL- $1 \beta$ group given $4 \mu \mathrm{g} / \mathrm{kg}$ body weight $(n=8)$, rats fed ad libitum $(n=8)$ and rats without treatment $(n=8)$ were included as control groups

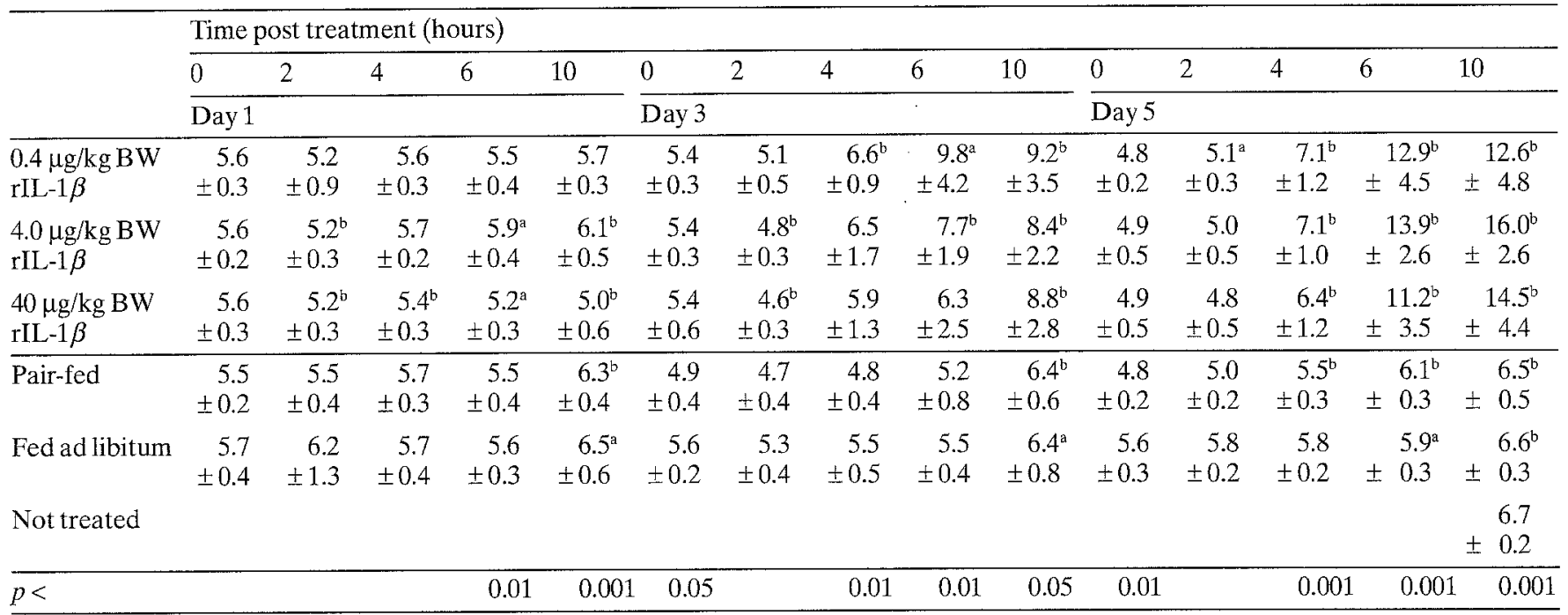

Means \pm SD. $p<: p$ values obtained by the Kruskal-Wallis test comparing all groups. ${ }^{\mathrm{a}} p<0.05$ and ${ }^{\mathrm{b}} p<0.01$ when comparing the $\mathrm{BG}$ after injection with the BG at 0 using Wilcoxon-Pratt test for paired-data

trol rats. No dose-response relationship between insulin level and rIL- $1 \beta$ dose was demonstrated, whereas plasma levels of glucagon and corticosterone was proportional $(p=0.01)$ and inversely correlated $(p=0.02)$, respectively. A dose-dependent effect of rIL- $1 \beta$ on body weight reduction and temperature increase was observed $(p<0.02$, data not shown). In the groups treated with $0.4,4.0$ or $40 \mu \mathrm{g} / \mathrm{kg}$ body weight of rIL-1 $\beta$, the average food intake per $100 \mathrm{~g}$ body weight was: $8.5 \pm 0.3,6.3 \pm 0.6$ and $4.6 \pm 1.0 \mathrm{~g}$, respectively $(p<0.001)$. In the pair-fed control group and the control group fed ad libitum the food intake was $6.4 \pm 1.1$ and $9.3 \pm 0.6 \mathrm{~g} / 100 \mathrm{~g}$ body weight, respectively. The body weight and food intake during treatment with the lowest dose of $\mathrm{rIL}-1 \beta(0.4 \mu \mathrm{g} / \mathrm{kg}$ body weight) did not differ from the control group fed ad libitum.

\section{Experiment 4}

Effects of repeated rIL-1 $\beta$ injections on the ultrastructure of the pancreas. We randomly selected and evaluated 23 and 17 islets, respectively, in four pancreata of rIL-1 $\beta$ treated rats and in four pancreata of vehicle-treated rats. No differences were found in the appearance of Beta cells with respect to lysis or granulation. A significant difference was recognized in the pericapillary spaces. The normal narrow peri-capillary space was well-preserved in $83 \%$ of the capillaries in control islets, both in the centre of the islets as well as in the islet periphery (Fig. $3 \mathrm{a}$, Table 4 ). In rats treated with IL-1 $\beta, 43 \%$ of the capillaries demonstrated enlargement of the peri-capillary spaces $(p<0.0001)$ (Figs. $3 \mathrm{~b}$ and c, Table 4$)$. This prominent widening was taken as morphological evidence for oedema formation, and was also found within the intercellular spaces of the Beta cell - Beta-cell contact zones although to a lesser degree (Fig. $3 \mathrm{~d}$ ) and, in the exocrine tissue to a even lesser degree. In areas of oedema, the Beta-cell plasma membranes demonstrated microvillous processes.

\section{Discussion}

The present study demonstrated that diabetic BG-values and low insulin levels were induced by repeated injections of $\mathrm{rIL}-1 \beta$ in normal rats compared to truly pair-fed controls. The time-dependent increase in BG levels and the diabetic state $10 \mathrm{~h}$ after the last injection of rIL- $1 \beta$ suggest that daily injections of rIL- $1 \beta$ cause a progressive inhibition of insulin release in vivo. Pancreatic insulin content was increased and no ultrastructural signs of Beta-cell damage were seen. These findings in vivo are very similar to the impairment of insulin release combined with increased islet insulin content and unaffected Beta-cell morphology reported for isolated islets within a defined window of the bimodal time- and dose-relationship of the effects of $I L-1$ on Beta-cell function $[24,25]$. The rIL-1 $\beta$ induced increase in $B G$ in vivo was reversible after three injections of rIL- $1 \beta$, i. e. the BG fell from $8-9 \mathrm{mmol} / 110 \mathrm{~h}$ after the third injection of rIL- $1 \beta$ to normal values before the fifth injection on the morning of day 5. More prolonged rIL-1 $\beta$ treatment or co-administration of other cytokines may be necessary to produce permanent diabetes as a result of Beta-cell damage.

Our findings cannot be explained by reduced food-intake caused by the well-known anorectic effect of IL-1. Firstly, control animals were pair-fed to receive exactly the same amount of food consumed by the rats treated with $4 \mu \mathrm{g} / \mathrm{kg}$ body weight of rIL- $1 \beta$, and the body weights were identical in the two groups throughout the study. Secondly, we have previously shown that 5 days of re- 

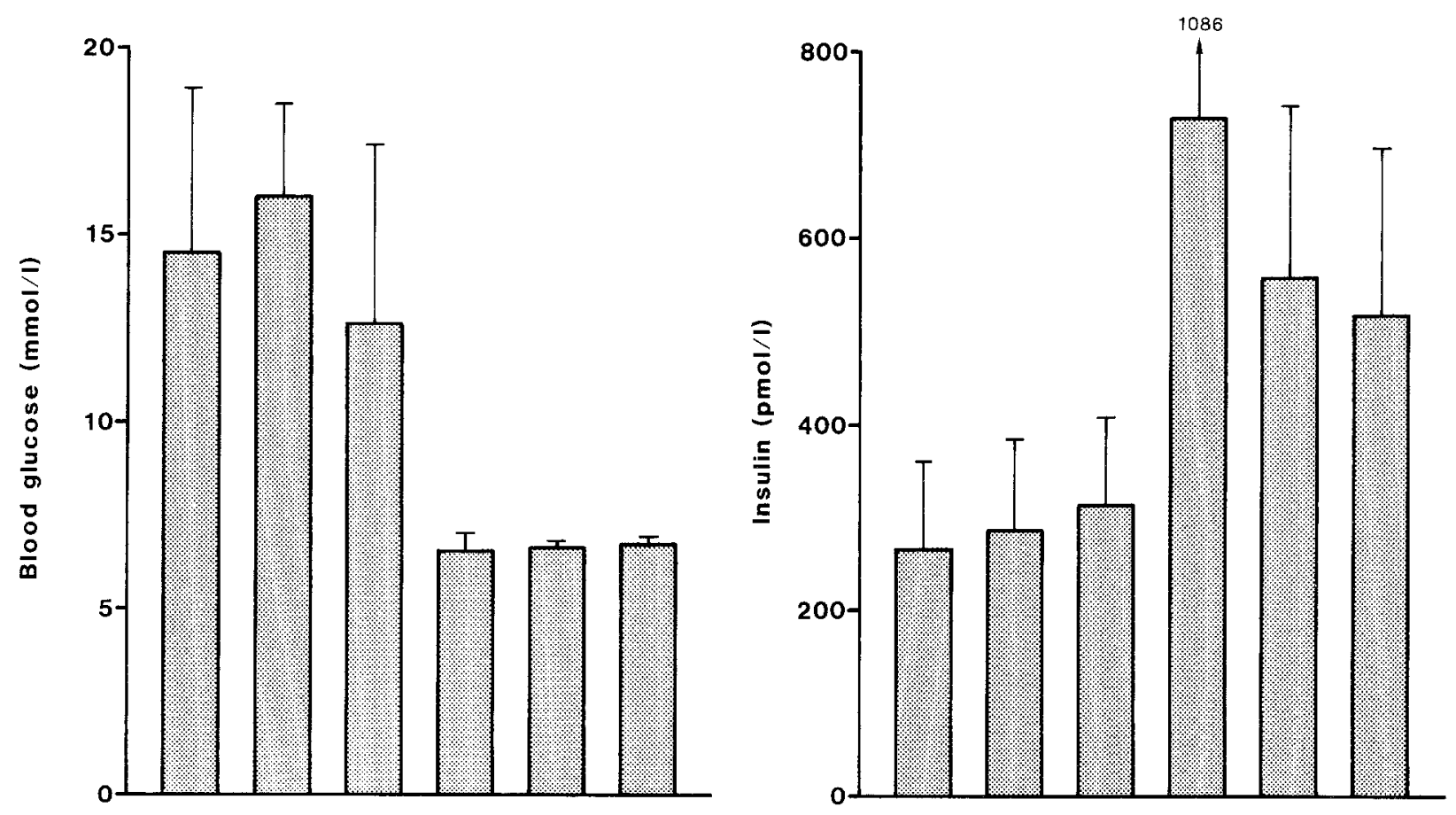

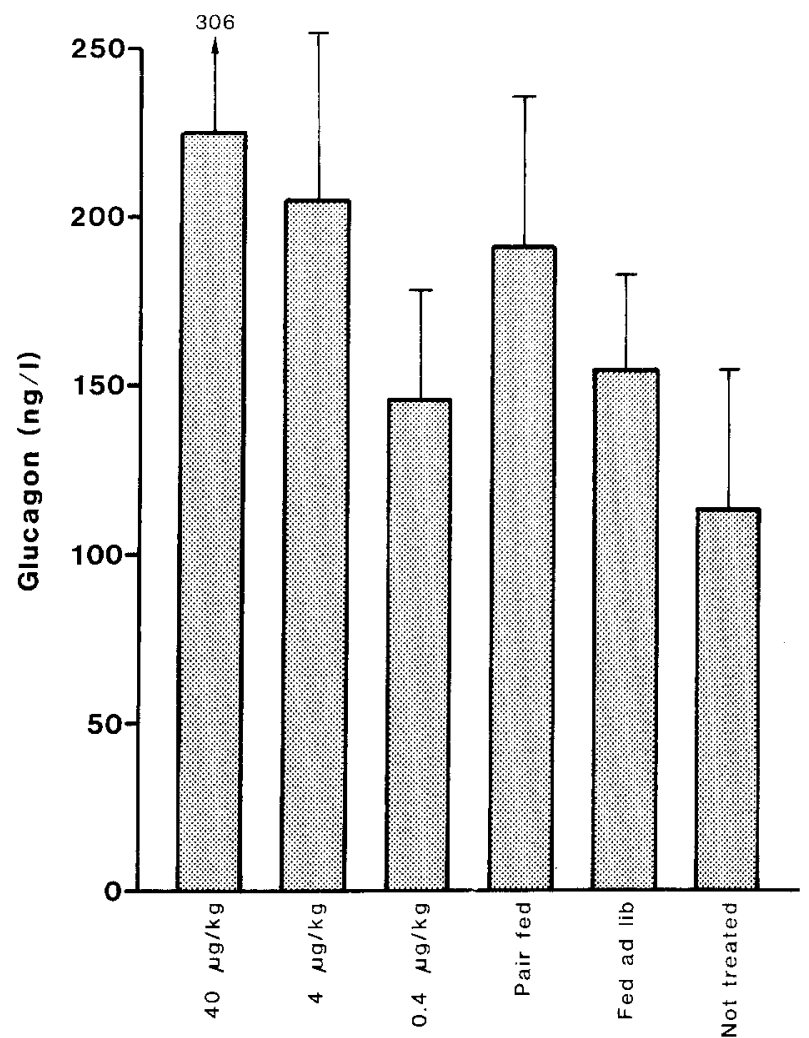

Fig. 2. Blood glucose and plasma concentrations of insulin, glucagon and corticosterone $10 \mathrm{~h}$ after the last of five daily injections of 40 $(n=12), 4.0(n=12)$ or $0.4(n=10) \mu \mathrm{g} / \mathrm{kg}$ body weight of human recombinant interleukin- $1 \beta$. Control rats treated with vehicle were

duced food-intake does not influence the BG levels during an IPGT [13]. Thirdly, $0.4 \mu \mathrm{g} / \mathrm{kg}$ body weight of rIL-1 $\beta$ caused hypoinsulinaemia and hyperglycaemia without reducing food intake.

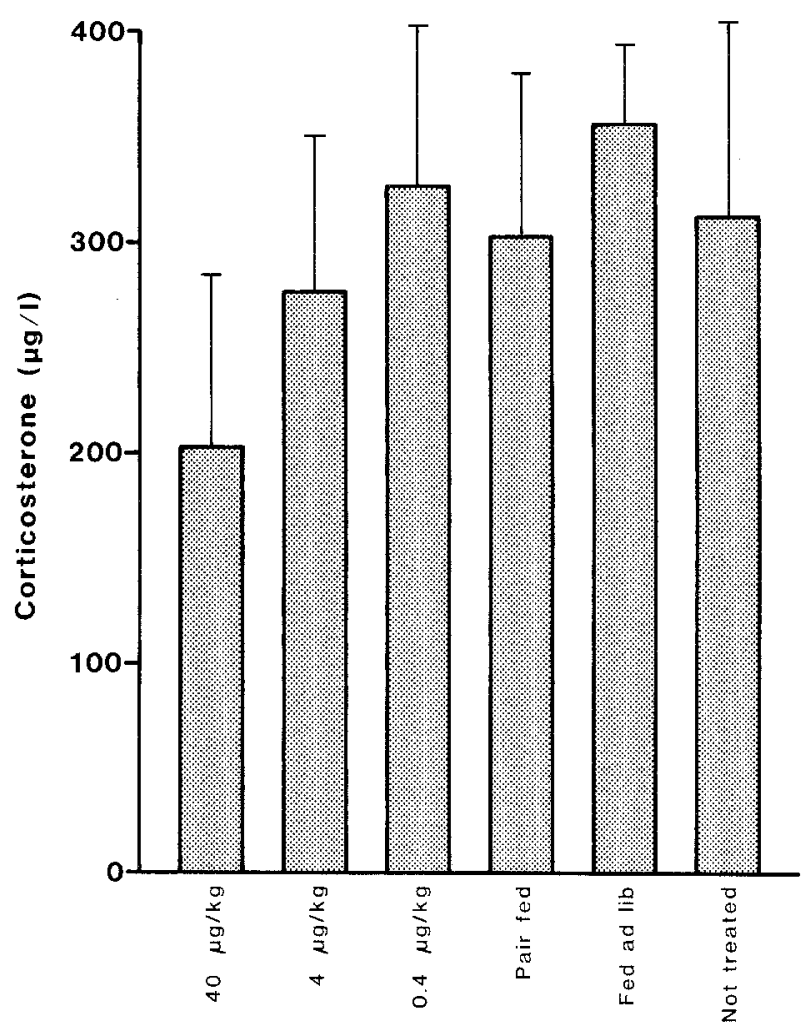

pair-fed with the rats injected with $4.0 \mu \mathrm{g} / \mathrm{kg}$ body weight of human recombinant interleukin- $1 \beta(n=8)$ or were fed at libitum $(n=8)$. A group of rats without treatment was included $(n=8)$. Means \pm SD. For significances and $p$ values see text

The hyperglycaemic and hypoinsulinaemic condition $10 \mathrm{~h}$ after the last injection of rIL- $1 \beta$ may seem to be in contrast to the potentiated insulin release during the IPGT $8 \mathrm{~h}$ earlier on the same day. However, supporting 


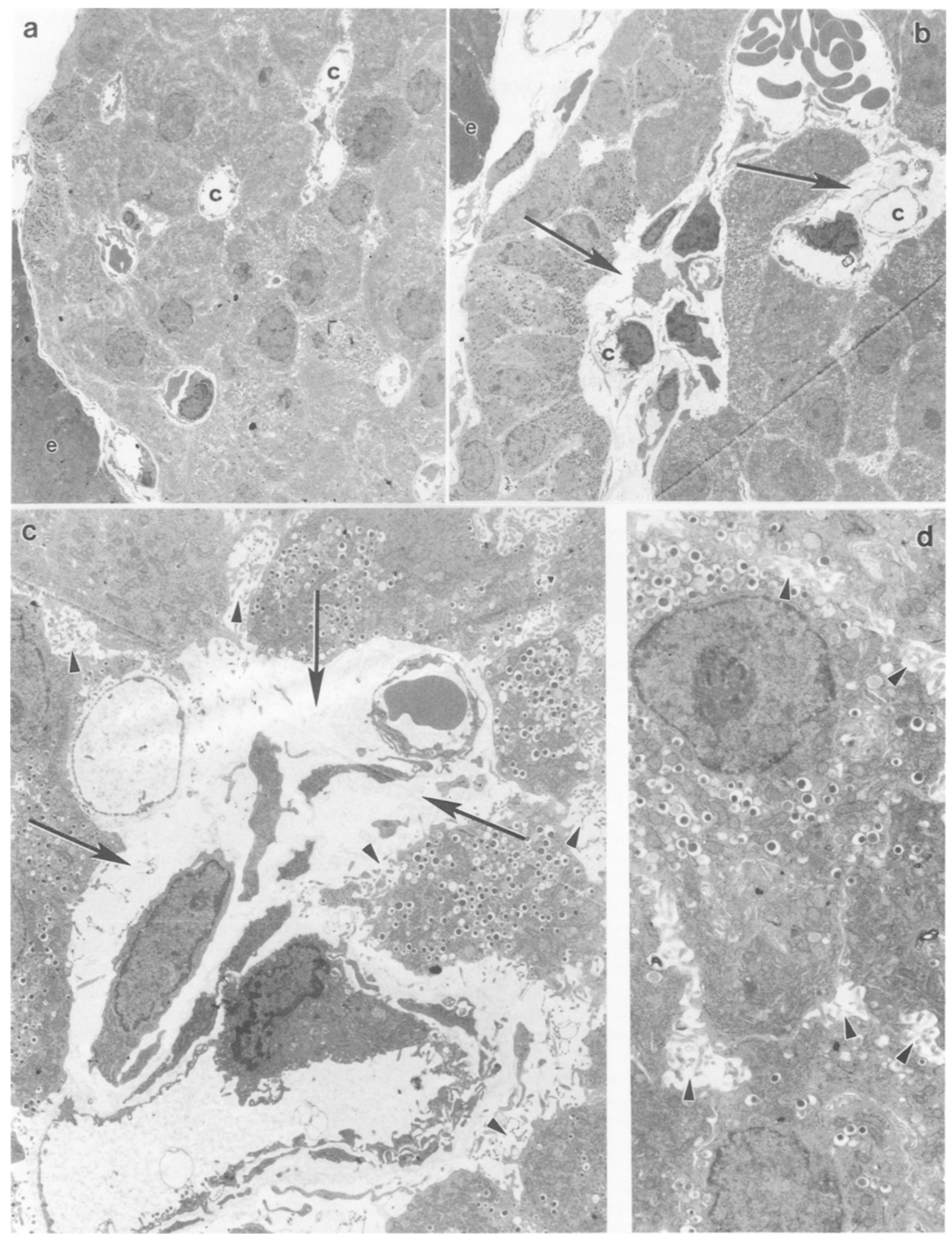

Fig.3a-d. Electron micrographs from pancreatic islets after the last of five daily injections with human recombinant interleukin- $1 \beta$ (rIL$1 \beta)(4 \mu \mathrm{g} / \mathrm{kg}$ body weight) or vehicle. a Low-power magnification $(1800 \times)$ of an islet from a control rat, showing perfectly normal structure. e, exocrine tissue, c, capillary. b Low-power magnification $(1800 \times)$ of an islet from an rIL- $1 \beta$ treated animal showing marked oedema formation within the endocrine tissue, most easily recog- nized as a considerable enlargement of the pericapillary spaces $(\rightarrow)$. c High power magnification $(5000 \times)$ of an islet capillary of a treated rat shows the oedema surrounding the capillary bed $(\rightarrow)$ and the numerous microvilli on the surfaces of surrounding Beta cells $(\downarrow)$. d Enlargement of extracellular spaces and concomitant microvillous Beta-cell surfaces are also found within the endocrine tissue of the rIL- $1 \beta$-treated rats $(\square)(7000 \times)$ 
Table 4. Rats were injected at 09.00 hours with $4 \mu \mathrm{g} / \mathrm{kg}$ body weight of recombinant interleukin- $1 \beta$ (rIL-1 $\beta$ ) or vehicle on each of five consecutive days. Two hours after the last injection the rats were anaesthetized and the pancreas was isolated for ultramorphological studies. All islets capillaries were counted and sorted for the appearence of oedema. The number of collapsed capillaries were also noted.

\begin{tabular}{|c|c|c|c|c|c|}
\hline & $\begin{array}{l}\text { No. } \\
\text { of islets }\end{array}$ & $\begin{array}{l}\text { No. of } \\
\text { capillaries }\end{array}$ & Normal & Oedema & Collapsed \\
\hline Vehicle & 17 & 309 & $257(83 \%)$ & $33(11 \%)$ & $19(6 \%)$ \\
\hline $\mathrm{rIL}-1 \beta$ & 23 & 189 & $86(46 \%)$ & $81(43 \%)^{b}$ & $22(12 \%)^{a}$ \\
\hline
\end{tabular}

Fisher's exact test. ${ }^{\mathrm{a}} p<0.05,{ }^{\mathrm{b}} p<0.0001$

our in vivo observations of a bimodal effect of rIL- $1 \beta$ on insulin release, recent in vitro studies demonstrated that exposure of isolated islets to rIL- $1 \beta$ for $60 \mathrm{~min}$ caused an initial increase of glucose-induced insulin release, followed by a progressive decline in Beta-cell function with a nadir after 10-12 h. Thereafter, Beta-cell function recovered and insulin secretion reverted to baseline values after $72 \mathrm{~h}$ [26].

The time-dependent increase in BG levels 6-10 hours after $\mathrm{r} \Pi-1 \beta$ injection on day 3 and 5 is similar to the observation in vitro that successive "hits" are increasingly devasting for the Beta cells [27]. Thus, inhibition of Beta cells exposed thrice to rIL $-1 \beta$ for $24 \mathrm{~h}$ in vitro was partly, but decreasingly reversible [27]. Reversibility of rIL-1 $\beta$ induced increase in BG was evident in the present study by the findings of normal $B G$ values before the fifth injection of rIL- $1 \beta$. Extended sampling for $\mathrm{BG}$ and insulin during the different 5 days of treatment is needed to disclose the nadir and the recovery period for $\mathrm{rLL}-1 \beta$ inhibited Betacell function in vivo.

Long-term treatment (weeks) with $10 \mu \mathrm{g} / \mathrm{kg}$ body weight of rIL- $1 \beta$ accelerates, whereas $0.5 \mu \mathrm{g} / \mathrm{kg}$ delays the onset of diabetes in the spontaneously diabetic BB rat [3]. In the NOD mouse long-term treatment with $8 \mu \mathrm{g} / \mathrm{kg}$ body weight of rIL- $1 \alpha$ prevents diabetes development [4], an effect not found in an earlier study using a similar dose of rIL-1 $\alpha$ [5]. Since IL-1 is a potent immunomodulatory agent, it is possible that the effects of IL-1 on the development of Type 1 diabetes in the BB rat and the NOD mouse are mediated through effects of IL-1 on the ongoing immune attack on the islets rather than through direct effects of IL- 1 on the Beta cells, but this question needs further investigation.

Plasma corticosteroid levels are known to be increased after a single injection of IL-1 [6]. To our knowledge this is the first demonstration of an inverse dose-response relationship between rIL-1 $\beta$ dose and plasma level of corticosterone $10 \mathrm{~h}$ after five injections of rIL- $1 \beta$. This finding may be explained by a time-dependent, bimodal effect of rIL- $1 \beta$ on corticosterone release, inhibition preceded by stimulation, analogous to the effect on insulin release in vivo reported herein and the in vitro effects of rIL- $1 \beta$ on Beta cells, thyroid cells and Leydig cells [1, 28, 29].

Enlargement of the pericapillary spaces was the only evident ultrastructural finding in the endocrine pancreas. This may be explained by increased permeability of the endothelial cells $[30]$ induced by circulating rIL- $-1 \beta$. We did not look for other markers of activation of endothelial cells e.g. induction of adherence molecules [31]. In areas of oedema formation, Beta cells showed plasma membrane microvillous processes. This observation may be related to reported changes in the cytoskeleton induced by monokines [32,33].

We confirmed that bolus injection of rIL- $1 \beta$ in normal rats causes a moderate decrease in $\mathrm{BG}[6-9,15]$ despite increases in glucagon and corticosterone [6]. We did not find an increase in plasma insulin concentration in parallel with the fall in $B G$ as found in vivo $[7,9,10,12]$ or in vitro $[1,24,25,34]$. Bolus injection of IL- $1 \beta$ to normal animals leads to increased glucose-stimulated insulin release ex vivo [35], and potentiates glucose or arginine stimulation of insulin secretion in vivo [36]. In our study we may have missed a plasma insulin peak after bolus injection of rIL$1 \beta$ due to the sampling intervals in our experimental design. Increased peripheral glucose uptake and utilization may contribute to the reduction in $\mathrm{BG}[8,12,37]$.

It has previously been suggested that rIL- $1 \beta$ confers insulin resistance in vivo [36] and in vitro [38]. It is likely that increased insulin resistance contributes to the impaired IPGT and the increasing pre- and post-prandial BG after three or five injections of rIL- $1 \beta$. A possible shift from increased to decreased glucose uptake or utilization may be explained by the $\mathrm{rIL}-1 \beta$ induced spikes in corticosterone release, and other IL-1 induced glucoregulatory hormones, leading to increased insulin resistance, or by direct effects of rIL- $1 \beta$ on peripheral tissue glucose uptake and liver glucose production. Indicative of a shift to a state of decreased insulin sensitivity during the 5-day treatment with IL-1, is the recent demonstration of an improved glucose tolerance after a single injection of rIL-1 $\beta[10]$. However, detailed studies of glucose metabolism were not performed.

Evaluation of the effects of prolonged exposure to rIL$1 \beta$ on pancreas function in vivo is complicated by concomitant rIL- $1 \beta$ induced effects on food intake, corticosterone secretion, and on peripheral tissue glucose disposal and production. However, it is demonstrated in the present investigation that functional effects of rIL- $1 \beta$ in vivo mimicks the functional effects of the cytokine on isolated islets in vitro, except that Beta-cell cytotoxity was not demonstrated. We conclude that multiple injections of rIL- $1 \beta$ may be diabetogenic in vivo by a combination of inhibition of Beta-cell function and decreased insulin sensitivity.

Acknowledgements. We thank Ms. L.Heding, Novo Nordisk A/S, Bagsvaerd, and Dr. H. Heindorf, Rigshospitalet, Copenhagen, Denmark, for measurements of plasma insulin and corticosterone, respectively. The skilful technical assistance by Ms. E. Schjerning, Ms. A. M. Flarup, Ms. B. Fich, Ms. B. Krog and Ms. B. Hansen is greatly appreciated. We thank Ms. A. Schlömer for excellent technical assistance in the morphology study. The authors are grateful to Mr. T. Momberg-Jørgensen and his staff at the Biological Department of Novo Nordisk A/S. Dr. Wogensen is the recipient of a fellowship award from the Juvenile Diabetes Foundation International, New York, USA (grant file \# 387263). The study was supported by the Danish Diabetes Association, the Danish Foundation for the Advancement of Medical Science, The Mr and Mrs Weimann, born Seedorf Foundation, Novo Nordisk A/S, Denmark and the Deutsche Forschungsgemeinschaft, grant 806/2-3 (V. Kolb-Bachofen). 


\section{References}

1. Mandrup-Poulsen T, Helqvist S, Mølvig J, Wogensen LD, Nerup J (1989) Cytokines as immune effector molecules in autoimmune endocrine diseases with special reference to insulin-dependent diabetes mellitus. Autoimmunity 4: 191-218

2. Palmer JP, Helqvist $\mathrm{S}$, Spinas GA et al. (1989) Interaction of $\beta$ cell activity and IL-1 concentration and exposure time in isolated rat islets of Langerhans. Diabetes 38: 1211-1216

3. Wilson CA, Jacobs C, Baker P et al. (1990) IL-1 $\beta$ modulation of spontaneous autoimmune diabetes and thyroiditis in the BB rat. J Immunol 144: 3784-3788

4. Jacob CO, Aiso S, Michie SA, McDevitt HO, Acha-Orbea H (1990) Prevention of diabetes in nonobese diabetic mice by tumor necrosis factor (TNF): similarities between TNF-alpha and interleukin 1. Proc Natl Acad Sci USA 87: 968-972

5. Satoh J, Seino H, Tanaka S et al. (1989) Recombinant human tumor necrosis factor $\alpha$ suppresses autoimmune diabetes in nonobese diabetic mice. J Clin Invest 84: 1345-1348

6. del Rey A, Besedowsky HQ (1987) Interleukin 1 affects glucose homeostasis. Am J Physiol 253: R794-R798

7. Bautista AP, Fletcher DJ, Volkman A (1989) Regulation of insulin and interleukin-1 release after Propionibacterium acnes induced macrophage activation in mice. Lab Invest 60: 447-454

8. del Rey A, Besedowsky HQ (1989) Antidiabetic effects of interleukin-1. Proc Natl Acad Sci USA 86: 5943-5947

9. Zawalich WS, Zawalich K (1989) Interleukin 1 is a potent stimulator of islet insulin secretion and phosphoinositide hydrolysis. Am J Physiol 256: E19-E24

10. Cornell RP (1989) Central interleukin-1-elicited hyperinsulinaemia is mediated by prostaglandins but not autonomics. Am J Physiol 257: R839-R846

11. Lang CH, Dobrescu C (1989) Interleukin-1 induced increases in glucose utilization are insulin mediated. Life Sci 45:2127-2134

12. Flores EA, Istfan N, Pomposelli JJ, Blackburn GL, Bistrian BR (1990) Effect of interleukin-1 and tumor necrosis factor/cachectin on glucose turnover in the rat. Metabolism 39: 738-743

13. Wogensen LD, Reimers J, Mandrup-Poulsen T, Nerup J (1991) Intraperitoneal injection of interleukin $1 \beta$ induces glucose intolerance in normal rats. Acta Endocrinol (Copenh) 124: 470478

14. Wang Y, Goodman M, Lumerman et al. (1989) In vivo administration of interleukin-1 inhibits glucose-stimulated insulin release. Diab Res Clin Pract 7:205-211

15. Wogensen LD, Helqvist $S$, Pociot F et al. (1990) Intraperitoneal administration of interleukin $1 \beta$ induces impaired insulin release from the perfused rat pancreas. Autoimmunity 7:1-12

16. Dalbøge H, Bayne S, Christensen T, Hejnæs K (1989) Cloning and expression of an interleukin $1 \beta$ precursor and its conversion to interleukin $1 \beta$. FEBS Lett $246: 89-93$

17. Wingfield P, Payton M, Tavernier J et al. (1986) Purification and characterization of human interleukin- $1 \beta$ expressed in recombinant Escherichia coli. Eur J Biochem 160: 491-497

18. Mølvig J, Sehested Hansen B, Worsaae H et al. (1990) Comparison of biological and immunological activities of human monocyte-derived interleukin $1 \beta$ and human recombinant interleukin $1 \beta$. Scand J Immunol 31: 225-235

19. Brk L (1983) New, sensitive rocket immunoelectrophoresis assay for measurement of the reaction between endotoxin and Limulus amoebocyte lysate. J Clin Microbiol 17: 1013-1020

20. Heding LG (1972) Determination of total serum insulin (IRI) in insulin-treated diabetic patients. Diabetologia 8:260-266
21. Heding LG (1971) Radioimmunological determination of pancreatic and gut glucagon in plasma. Diabetologia 7: 10-19

22. Svenningsen A, Dyrberg T, Markholst H, Binder C, Lernmark $\AA$ (1986) Insulin release and pancreatic insulin is reduced in young prediabetic BB rats. Acta Endocrinol (Copenh) 112: 367-371

23. Spurr A (1969) A low-viscosity epoxy resin embedding medium for electron microscopy. J Ultrastruct Res 26: 31-43

24. Comens PG, Bryan AW, Unanue ER, Lacy PE, McDaniel ML (1987) Interleukin 1 is a potent modulator of insulin secretion from isolated rat islets of Langerhans. Diabetes 36: 963-970

25. Spinas GA, Mandrup-Poulsen T, Mølvig J et al. (1986) Low concentrations of interleukin-1 stimulate and high concentrations inhibit insulin release from isolated rat islets of Langerhans. Acta Endocrinol (Copenh) 113: 551-558

26. Eizirik DL, Bendtzen K, Sandler S (1991) Short exposure of rat pancreatic islets to interleukin- $1 \beta$ induces a sustained but reversible impairment in $\beta$-cell function. This effect is influenced by protease activation, gene transcription and protein synthesis. Endocrinology 128: 1611-1616

27. Helqvist S, Zumsteg UW, Spinas GA et al. (1991) Repetitive exposure of pancreatic islets to interleukin- $1 \beta$. An in vitro model of pre-diabetes? Autoimmunity 10: 311-318

28. Rasmussen $\AA K$, Bech K, Feldt-Rasmussen U et al. (1988) Interleukin-1 affects the function of cultured human thyroid cells. Allergy 43: 435-441

29. Verhoeven G, Cailleau J, Van Damme J, Billiau A (1988) Interleukin-1 stimulates steroidogenesis in cultured rat Leydig cells. Mol Cell Endocrinol 57: 51-60

30. Martin S, Maruta K, Burkart V, Gillis S, Kolb H (1988) IL-1 and IFN- $\gamma$ increase vascular permeability. Immunol 64: 301-305

31. Wawryk SO, Novotny JR, Wicks IP et al. (1989) The role of the LFA/ICAM-1 interaction in human leucocyte homing and adhesion. Immunol Rev 108: 135-161

32. Wogensen LD, Kolb-Bachofen V, Christensen P et al. (1990) Functional and morphological effects of interleukin- $1 \beta$ on the perfused rat pancreas. Diabetologia 33: 15-23

33. Scanlon M, Laster SM, Wood JG, Gooding LR (1989) Cytolysis by tumor necrosis factor is preceded by a rapid and specific disolution of microfilaments. Proc Natl Acad Sci USA 86: 182-186

34. Wogensen LD, Mandrup-Poulsen T, Markholst H et al. (1988) Interleukin-1 potentiates glucose stimulated insulin release in the isolated perfused pancreas. Acta Endocrinol (Copenh) 117: 302-306

35. Yelich MR (1990) In vivo endotoxin and IL-1 potentiate insulin secretion in pancreatic islets. Am J Physiol 258: R1070-R1077

36. Cornell RP (1989) Hyperinsulinemia elicited by interleukin-1 and nonlethal endotoxemia in rats. Circ Shock 28:121-130

37. Bird TA, Davies A, Baldwin SA, Saklatvala J (1990) Interleukin 1 stimulates hexose transport in fibroblasts by increasing the expression of glucose transporters. J Biol Chem 265: 13578-13583

38. Filkins JP (1985) Do monokines contribute to insulin resistance in septic shock? Physiologist 28: 331 (Abstract)

Received: 2 May 1991

and in final revised form:9 December 1991

Dr. J.Nerup

Steno Memorial and Hvidøre Hospital

2 Niels Steensensvej

DK-2820 Gentofte

Denmark 